\title{
tont
}

逆問題解法による拡散光断層イメージング

\author{
山田 幸生 $* * *$ ，高 峰**
}

*電気通信大学 ( ₹182-8585東京都調布市調布ヶ丘1-5-1)

**産業技術総合研究所 ( $3305-8564$ 茨城県つくば市並木1-2)

\section{Diffuse Optical Tomography by Inverse Problem Technique}

\author{
Yukio YAMADA $* * * *$ and Feng GAO** \\ *University of Electro-Communications, 1-5-1 Chofugaok, Chofu, Tokyo 182-8585 \\ **National Institute of Advanced Industrial Science and Technology, 1-2 Namiki, Tsukuba, Ibaraki 305-8564
}

(Received July 22, 2002)

\begin{abstract}
Diffuse optical tomography using near infrared light has been developed for the purpose of imaging oxygenation states in human body. The technology is classified into three groups by measuring techniques; CW, frequency and time domain techniques. This review describes light propagation in biological tissues and their optical properties for solving the forward problem in the image reconstruction algorithm which resorts to the technique of inverse problems. Recent development of the algorithms are also reviewed and future applications are described.
\end{abstract}

Key Words: Diffuse optical tomography, Oxygenation state, Photon diffusion equation, Inverse problem, Image reconstruction

1.はじめに

生体組織の断層像を光により得ようとする光断層イ メージング，いわゆる光CTはその安全性，簡便性のゆえ に，医学的な臨床応用の価值が高く，また，生物学的な 研究でも有用と考えられ1)，1990年代初めから世界各国で 研究開発が行われている。日本でも通産省のプロジェク トとして1994年から7年間実施され，多くの基礎研究と技 術開発が実施され，世界で初めて時間分解方式の光断層 イメージング装置を開発し, 生体模擬試料を対象として 光断層画像を得ることに成功した。しかし, 臨床応用に 至るにはまだいくつかの性能向上を必要としている。そ の中の一つに，画像再構成を行うアルゴリズムの改良が 挙げられる．X線が体内を直進することを仮定しているX 線CTの画像再構成アルゴリズムは, 光が体内で強く散乱 される光CTでは適用できず，光CTのアルゴリズムは基本 的に一般的な逆問題解法とならざるを得ない。 そのた め, 数学的に複雑な処理を行うことになり, これまで3次 元画像を短時間で得ることはできなかった。

しかし, 最近のこの分野における急速な進展は, 近い 将来に3次元の光CT画像がほぼリアルタイムで得られるの ではないか, との展望を抱かせている. 光CTによってヒ 卜頭部の断層像が得られれば脳内の傷害だけでなく, 脳 機能を光によって3次元的に計測することが可能となる.

本稿では, まず生体内の光伝播現象について説明し,
それを基礎とした光CTの画像再構成アルゴリズム, 最近 の光CT装置と得られた画像，そして脳機能計測に関する 展望について解説する.

\section{2. 近赤外光による脳活動測定と生体内光伝播}

\section{1 近赤外光と脳活動}

血液は動脈血と静脈血では色が異なる。これはFig. 1に 示すように酸素化へモグロビンと脱酸素化へモグロビン とで光の吸収スペクトルが異なるからである。従って,

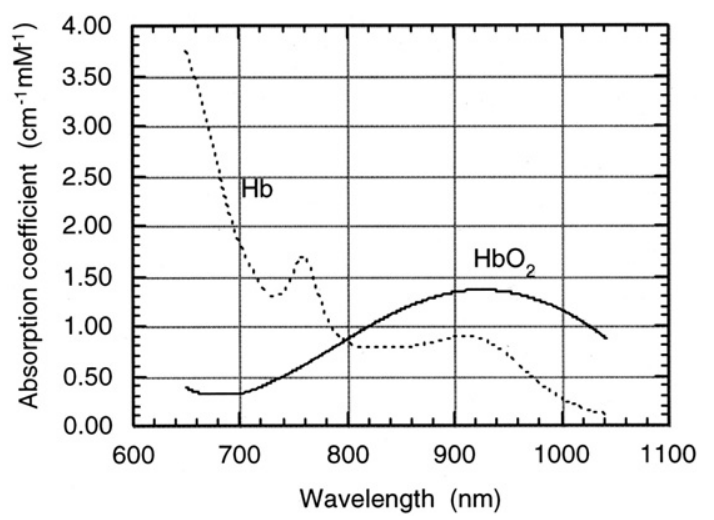

Fig. 1 Spectra of the molar absorption coefficients of oxygenated and deoxygenated hemoglobin $\left(\mathrm{HbO}_{2}\right.$ and $\mathrm{Hb})$. 
血液の吸収スペクトルを測定すれば血液の酸素化度およ び血液量などを知ることができる。これが近赤外光によ る血液あるいは組織の酸素化度測定の原理であり, それ を断層像として描き出すのが光CT(光断層イメージング) である、脳活動に伴う血液状態の变化を断層像として描 き出すことができれば光CTによって脳機能を調べること ができる。

近赤外光を用いる理由はその波長域の光が生体組織を 透過しやすいためである. 生体組織の光吸収特性は生体 組織中に存在する多くの光吸収物質が重なり合ったもの となっている. その中でも可視光から赤外光にかけて強 い吸収を示す物質は, 生体の約 $60 \%$ 以上を占める水と赤 血球中のへモグロビンである。水は赤外光域で特に吸収 が強く, $1.0 \mu \mathrm{m} よ り$ 短い波長では吸収が弱い. 一方, へモ グロビンは可視光域で吸収が強く, $700 \mathrm{~nm}$ よ長い波長 では吸収が弱くなる。へモグロビンと水の吸収が弱い700 $\mathrm{nm}$ から $1.0 \mu \mathrm{m}$ の近赤外光域は光に関する生物学的空と呼 ばれ，この近赤外光は生体組織を透過しやすい. 最新の 光検出技術を用いれば不透明な生体組織であっても厚さ $10 \mathrm{~cm}$ の組織を通過した近赤外光を検出することは可能で ある、

しかし，生体組織は光を吸収するだけでなく散乱し， 散乱は吸収よりも2桁以上強い. そのため取り出したい吸 収の情報は散乱による光の減衰の中に埋もれ, それを取 り出すことは容易ではない. しかし, 近年の研究の進展 により生体内の光伝播に関する解析手法が確立し, いわ ゆる逆問題手法によって吸収の情報を取り出すことが可 能となってきた。 また, 吸収情報だけでなく, 散乱情報 も同時に取り出すことができる。

光の散乱特性は吸収とは対照的に波長に対して単調な 変化を示し, 波長が長くなるほど散乱は徐々に弱くな る.また, 生体組織による光の散乱パターンは非常に強 い前方散乱を示す。これは生体組織による光の散乱が粒 子の集合体による光の散乱とは様子が異なり, 細胞膜に よる光の屈折や細胞内の微小器官による散乱などが複雑 に重なった現象であることがその原因であると考えられ ている.脳活動に伴う血液状態の変化は吸収の変化をも たらす一方, 神経の興奮に伴う細胞内外の物質濃度の変 化は細胞内外の屈折率変化をひきおこし, 結果として散 乱の変化をもたらす。

従って, 光の吸収・散乱特性值の変化に関して頭部内 断層像を得ることができれば, 脳機能をその神経活動お よび血液状態変化によって調べることができる.

\section{2 生体組織中光伝播の記述}

生体組織のような散乱・吸収媒体中の光伝播を記述す る最も基本的な方程式は光輸送方程式であり, 式(1)のよ うな非定常偏微分積分方程式で表される2).

$$
\begin{aligned}
& \left\{\frac{1}{c} \frac{\partial}{\partial t}+\hat{\mathbf{s}} \cdot \nabla+\left(\mu_{s}+\mu_{a}\right)\right\} I(\mathbf{r}, \hat{\mathbf{s}}, t) \\
& =\mu_{s} \int_{4 \pi} p\left(\hat{\mathbf{s}}^{\prime}, \hat{\mathbf{s}}\right) I\left(\mathbf{r}, \hat{\mathbf{s}}^{\prime}, t\right) d \hat{\mathbf{s}}^{\prime}+q(\mathbf{r}, \hat{\mathbf{s}}, t)
\end{aligned}
$$

ここで $I(\mathbf{r}, \hat{\mathbf{s}}, t)$ は点 $\mathrm{r}$, 方向 $\hat{\mathbf{s}}$, 時間 $t$ (ピコ秒オーダー $)$ にお
ける光強度で $c$ は光速, $\mu_{s}, \mu_{a}$ は散乱係数および吸収係数, $p\left(\hat{\mathbf{s}}^{\prime}, \hat{\mathbf{s}}\right)$ は散乱の位相関数, $q(\mathbf{r}, \hat{\mathbf{s}}, t)$ は媒体内の光源強度で ある。この方程式は厳密であるが, 複雑であるため数值 解を求めることも容易ではないため, 次の光拡散方程式 がよく用いられる。

$$
\frac{1}{c} \frac{\partial \phi(\mathbf{r}, t)}{\partial t}=\nabla[D(\mathbf{r}) \nabla \phi(\mathbf{r}, t)]-\mu_{a} \phi(\mathbf{r}, t)+Q(\mathbf{r}, t)
$$

ここで, $\phi(\mathbf{r}, t)$ は点 $\mathrm{r}$, 時間 $t$ (ピコ秒オーダー)における積分 光強度 $(I(\mathbf{r}, \hat{\mathbf{s}}, t)$ の全方向 $\hat{\mathbf{s}}$ に関する積分 $)$ で, $D(\mathbf{r})=1 / 3 \mu_{s}^{\prime}$ は光拡散係数, $\mu_{s}^{\prime}=(1-g) \mu_{s}$ は等価散乱係数, $g$ は非等方 散乱パラメー夕(位相関数の余弦平均), $Q(\mathbf{r}, t)$ は光源強度 である。

式(2)は適当な境界条件の下で, 差分法や有限要素法な どで数值的に解く事ができ, 簡単な場合には解析解も得 られる。式(2)は式(1)を等方散乱を仮定した光拡散近似に よって簡略化したものであるため, 早い時間や光の入射 点近傍および境界面近傍では精度が悪い. しかし, 数 $\mathrm{cm}$ 以上の大きさの生体に対しては入射点及びその近傍以外 では，この問題は無視して良い。この光拡散方程式は, 温度や物質の拡散現象と同様に, 強い散乱体内では光が 光強度の勾配に依存して拡散的に広がって行くことを意 味している。

式(1)または式(2)が光断層イメージングの画像再構成ア ルゴリズムで生体内光伝播の順問題解析に主に用いられ る基礎式であり, 対象物内部の光学特性值 (吸収および散 乱係数)の空間分布を求めることが画像再構成の目標とな る.

なお，式(1) (2) は決定論的な光伝播現象の記述である が, 統計論的記述法もあり, その代表はモンテカルロ法 である.モンテカルロ法は光をエネルギ束の集合と考 え, 各エネルギ束の経路を散乱・吸収係数などの光学特 性值を統計的に満足するように決め, 逐一経路を追跡す る手法であり, 統計的に式(1)や式(2)を実現する。しか し, 計算時間が長いため, 画像再構成アルゴリズムで繰 り返し用いることはほとんどない。

Table 1は波長794 nmでのブタ頭部組織の光学特性值3)を 示している。ヒト組織でも数值はほとんど同じであり, 散乱は吸収よりも2桁あるいは3桁も強いことが分かる。

\section{3. 画像再構成アルゴリズムの概要}

光CTの画像再構成アルゴリズムは，一般にFig. 2のよう な逆問題解法4) を用いる。

対象物に光 (連続光, 強度変調光またはピコ秒パルス 光)を照射し, 内部で散乱吸収を受けた光の内, 対象物表 面に現れた光を検出する. 光は拡散的に広がるため対象

Table 1 Measured $\mu_{s}$ ' and $\mu_{a}$ using a time-resolved (TR) method. ${ }^{3)}$

\begin{tabular}{ccc}
\hline$(\lambda=794 \mathrm{~nm})$ & $\mu_{s}{ }^{\prime}\left(\mathrm{mm}^{-1}\right)$ & $\mu_{a}\left(\mathrm{~mm}^{-1}\right)$ \\
\hline Pig skin & 2.7 & 0.003 \\
\hline Pig skull & 2.5 & 0.002 \\
\hline Pig brain & 2.9 & 0.004 \\
\hline
\end{tabular}


Optical-CT by Solving the Inverse Problem

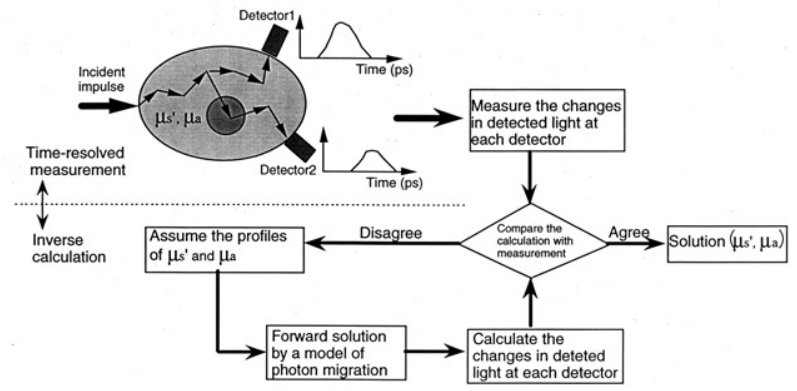

Fig. 2 Concept of the algorithm for diffuse optical tomography.

物の多くの点で同時に計測可能である。照射点を移動 し，多くの測定デー夕を得る.

一方で, 対象物内部の光学特性值分布を仮定して前述 の光伝播を記述する方程式を解き, その結果として表面 での光強度分布や光強度の時間変化を得ることができ る。これらの計算結果が実際に測定された光強度分布や 時間変化と一致すれば，仮定した光学特性值分布を正し いとして, 再構成画像が得られたと考える。一致しない 場合には不一致の程度に応じて光学特性值分布を仮定し なおして再び光伝播の順問題計算を行い，一致するまで このプロセスを繰り返す。

光学特性值分布を仮定しな书す手法としては, いわゆ るNewton-Raphson法を用いるのが標準的であり，その 他, ART(Algebraic Reconstruction Technique)法や Levenberg-Marquardt法など, 逆問題解法で開発された各種 の最適化手法が組み合わせて使用される。

基本的に光CTのアルゴリズムは, 非線形逆問題であ り, 他の逆問題と同様に悪条件で, 測定数よりも未知数 の方が多く不定条件となる場合が多い。そのため, 解が 一義的に求まらず，局所解に陥る可能性もある。年れを 避けるために，事前情報を組み入れたり，解の上限や下 限を設定することなどによって情報を増やすことが多 い、いずれにしろ繰り返しや行列を求める計算が大きな 負担となる。

このような光CTの逆問題アルゴリズムは1994年ごろに 英国で初めて開発されたが5), その後, 多くのグループが 開発を行い，画像の質の向上が図られると共に2次元から 3次元へと発展している.

\section{4. 光CT測定法の分類}

画像再構成アルゴリズムの入力データを得るための測 定法としては光源で分類すると次の 3 種類がある.

(1)連続光法 ( CW domain)

(2)強度変調光法 (Frequency domain)

(3)時間分解測定法 (Time domain)

連続光法は, 一定強度の光を照射し, 検出光の強度を 測定する手法である. 装置もアルゴリズムも最も簡便で あるが, 光強度の絶対值の校正が困難で, デー夕数も少 ないため, 得られる画像の質が他の測定法に比べれば劣
る傾向にある，短時間測定が可能である。

強度変調光法は, 連続光を数百MHzから数 $\mathrm{GHz}$ までの 周波数に变調して対象物に照射し, 検出光の位相変化, 交流成分の振幅変化を主に測定する. 複数の周波数を用 いることにより独立な入力デー夕数を増やすことができ る。装置は比較的簡便である。

時間分解測定法は, ピコ秒程度の極短パルス光を照射 して, ピコ秒の時間分解能を持つ検出器で測定する. 独 立な入力デー夕数が非常に多くなるため, 最も良い画像 が得られるが, 計算時間・容量が大幅に増加する。装置 も比較的大きくなり測定時間も長くなる.

以下に, 各測定手法を用いた光CT研究開発における最 新の成果を紹介する。

\section{5. 連続光法による光CT}

連続光法の短時間測定可能という長所を活かして, 毎 秒数枚の画像を取得して, 生理学的な速い変化を光CT画 像として捉える装置が米国のBarbourらのグループ6)に よって開発され，製品化されている. $800 \mathrm{~nm}$ 付近で最大 4 波長までのdiode laserを光源とし，25個所の照射点と 32 チャンネルの検出器を持つことができる. 高速スキャン によって毎秒3画像のデータが取得可能である. 画像再構 成は2次元の定常光拡散方程式を支配方程式として逆問題 解法アルゴリズム7)を用い, 散乱係数は既知として吸収係 数のみの再構成を行うため計算時間も短い.

この高速光CTにより, 生体の速い動的な生理学的反応 を調べることができる。例えば組織内血流量の体温変化 に反応する様子が画像化され, 反応の違いから正常組織 と腫瘍を区別可能であると報告されている。

\section{6. 強度変調光法による光CT}

例としてPogueらのグループが開発した16チャンネルの 装置8) が挙げられる。 $660 \mathrm{~nm}$ から $826 \mathrm{~nm}$ までの4波長を用 い, diode laserからの光は100 MHzに変調され光ファイバ によって対象物に送られる. 光ファイバはアクチュエー 夕によって対象 (乳房) に接触・固定され, 変調光の位相と 振幅変化が測定される。一枚の画像用デー夕を取得する のに約 30 秒必要とする。.

画像再構成アルゴリズムは式(2)をfrequency-domainに変 換した式を基礎方程式として逆問題を解く. 2次元㧍よび 3次元のアルゴリズムが開発9)され, 吸収と散乱係数の絶 対值分布を同時に画像として再構成が可能である。

この装置は臨床応用として乳癌診断に利用されてい る.

\section{7. 時間分解法による光CT}

この手法を用いた装置は世界に先駆けて日本 ${ }^{10)}$ が開発 し，その後英国11)でも開発された。

英国で開発された装置は，光源にTi:sapphireレーザーを 用い, $800 \mathrm{~nm}$ 付近でピコ秒パルス光(パルス幅約 $1 \mathrm{ps}$ )を 80 
MHzで発生させる。時間分解計測はsingle photon counting 法を用いており, 装置全体の時間分解能は約 $150 \mathrm{ps}$ であ る。全32チャンネルのデータを収集するのに10２0分必 要とする。この装置を用いて乳房ファントムの3次元画 像12)などを得ているが, 画像再構成アルゴリズムでは時 間分解データを全て活用してはおらず，得られた時間分 解曲線から平均飛行時間など, 曲線の特徵的な数值を抽 出し, 限られた数のデータを入力データとしている。そ のため, 得られた画像の質は連続光法や強度変調光法と 同等となっている.

日本で開発された装置の概略はFig. 3に示されている. $761 \mathrm{~nm}, 791 \mathrm{~nm}, 830 \mathrm{~nm}$ の3波長でパルス幅が約100 psの 極短パルス光がダイオードレーザーより $5 \mathrm{MHz}$ の繰り返し で射出される. 光スイッチで波長を選択し, 計64本の光 ファイバ束の一つに導かれる，1本の光ファイバ束は照射 と検出を兼ねる構造となっている. 光ファイバ束は対象 物表面に接触して固定され，1本が照射用で他は検出用と なる．各検出光は独立並行にフィルターで減光されて高 速の光電子増倍管に導かれ, CFD (Constant Fraction Discriminator) とTAC (Time to Amplitude Converter)によっ て single photon counting法で時間分解測定される. 装置全 体としての時間分解能は約 $150 \mathrm{ps}$ である. 微弱光を検出し ているため測定時間が長く, 64本の光ファイバ束を用い ると1画像のデー夕収集に約20分, 32本で約5分, 16本で 約 2 分となる。脳機能の計測には 1 分以下が望まれてい る.

直径 $80 \mathrm{~mm}$ で, 光学特性值が生体組織に類似した一様な 円柱ファントムを用いて測定された時間分解曲線の例を Fig. 4に示す. 照射パルス光の半值幅約 $100 \mathrm{ps}$ に対し, 照 射点より45度, 78度, および180度の点における検出パル ス光の波形が示されており, 照射点より遠いほどパルス 幅が大きくなる様子が分かる。このような時間分解測定 結果を入力データとして逆問題アルゴリズムによって光 学特性值分布を画像として再構成する.

円柱ファントムの内部に吸収係数が大きい小円柱が 2 本 存在する場合に得られた画像の例がFig. 5であり, 小円柱

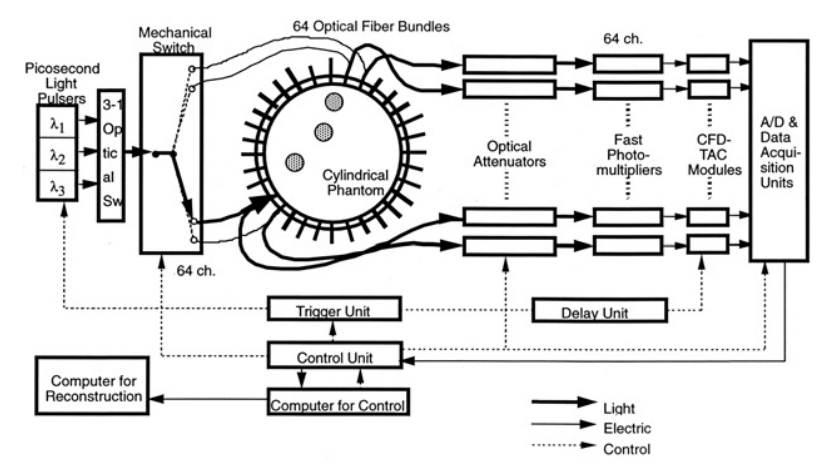

Fig. 3 Multi-channel time-resolved diffuse optical tomographic imaging system (The picosecond diode lasers, photomultipliers, CFD/TAC modules, A/D converters and data acquisition units were developed by Hamamatsu Photonics, and other components, computer control and whole system were arranged by Shimadzu Corporation. ${ }^{9}{ }^{9}$ ).

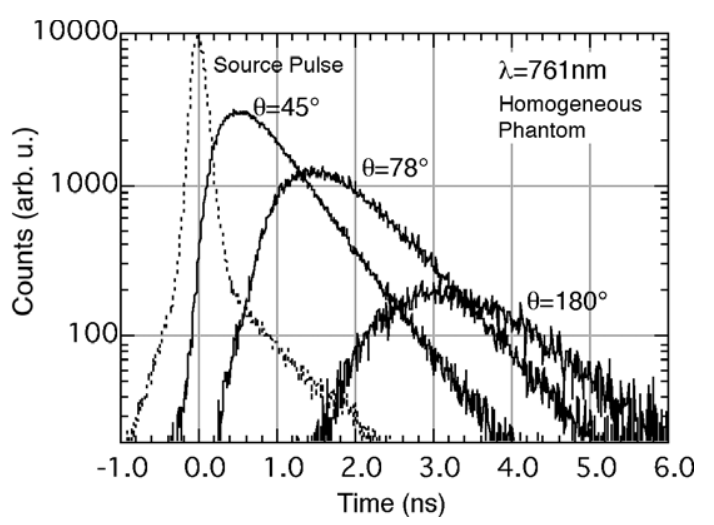

Fig. 4 Measured time-resolved transmittances through a homogeneous phantom at three azimuthal angles from the source position. The ordinate is the photon counts (in an arbitrary unit) measured by the detector. The peak of the source pulse is normalized to 10000 .
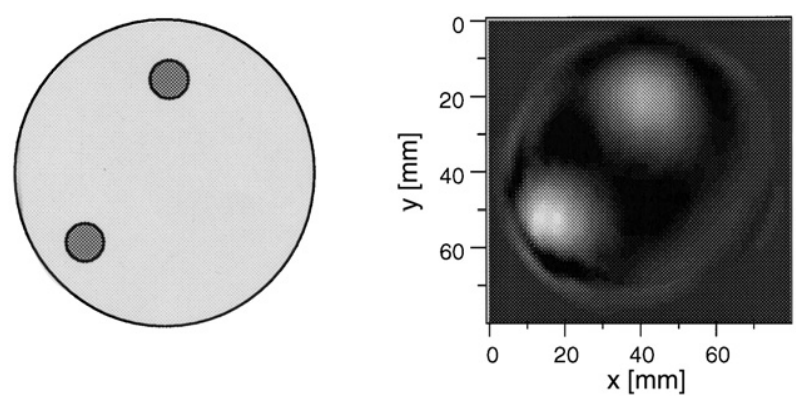

Fig. 5 A reconstructed absorption image of a cylindrical phantom which has two small absorbers at the wavelength of $791 \mathrm{~nm}$. The image was reconstructed from CW data.

の存在を再構成画像で明らかに知ることができる。しか し, 空間分解能は約 $20 \mathrm{~mm}$ で, 再構成された吸収係数も真 の值の約40\%にとどまっており，画像の質は必ずしも良 いとは言えない。これは，アルゴリズムが未熟で時間分 解測定デー夕を全て活用することができなかったためで ある。

時間分解測定法は, 逆問題解法において多くの独立な 入力デー夕を提供し，良い画像を得るために最も優れた 測定法であることは理解されてはいた。しかし，計算時 間や計算機の容量が大幅に増加して計算が困難になるこ とから，これまで時間分解データを全て活用して画像を 再構成する試みはなされていなかった。 そこで, 筆者ら は時間分解測定デー夕を全て活用した場合に画像の質が どれだけ改善されるかをシミュレーションによって調べ た13).

対象は短時間での計算を可能とするために 2 次元で直径 $80 \mathrm{~mm}$ のウとし, 内部に吸収係数や散乱係数の異なる小円 を配した. シミュレーションによって検出される時間分 解曲線を求め, それを入力データとし, 逆問題アルゴリ ズムによって吸収および散乱係数の画像を再構成した。 時間分解曲線は $160 \mathrm{ps}$ の時間ステップで分割し，各時間ス テップの光強度を入力データとした. 時間分解曲線の全 時間幅は $8 \mathrm{~ns}$ であり，全時間ステップ数は51となった．照 射点 16 個, 検出点 9 個であり, 入力デー夕総数は $16 \times 9 \times$ 
$51=7344$ 個である. 入力データ数は時間分解曲線の特徵 的なデータしか使わない場合の10倍以上である.

円内部に直径 $10 \mathrm{~mm}$ で中心間距離が $16 \mathrm{~mm}$ 離れた 2 個の 強い吸収体が存在する場合の結果をFig. 6に示す. Fig. 6は (a) CWデー夕のみ, (b) 平均飛行時間 $<t>0$ み, (c) 平均飛 行時間 $<t>$ と飛行時間の分散 $<t^{2}>(\mathrm{c} 2),(\mathrm{d})<t>$ と $<t^{2}>(\mathrm{c} 2)$ と飛行時間の3次モーメント $<t^{3}>(\mathrm{c} 3)$, (e) 時間分解デー夕 の絶対值, (f) 時間分解データの相対值, の6種類の入力 デー夕を用いた場合について画像を比較している。時間 分解曲線の特徵的デー夕を用いた (a)から (d) までの画像は 2つの小円柱を分離できないが，時間分解デー夕を全て用 いた画像 (e)と (f) では明確に分離できており, 空間分解能 は大幅に向上している.

また，2つの小円柱の中心線を結ぶ線上での吸収係数分 布を調べると真の分布に対し，(a)から (d) はピーク值が30 \%以下であるが，(f)ではピーク值が約60\%と大幅に真の 值に近づいている.

ここで示した空間分解能と定量性たけでなく, 精度, ノイズに対する強さなども格段に向上し, 画像の質が大 幅に向上することが証明された。

しかし, 予想された通り, 計算時間は大幅に増加し, (e)や (f)の計算時間は，(a)の50倍以上，(c)の10倍以上と なった. また, 3次元の計算を行えばさらに計算の負担が 増加すると考えられる. 今後, 時間分解デー夕を十分に 活用しながらも計算負担が小さいアルゴリズムの開発が 期待される。

また, 開発された時間分解測定装置はいずれもSingle Photon Counting法を採用しているため, 測定時間が長くな り, 生体における秒単位・分単位の速い変動に対応する ためには他の時間分解測定法が必要となろう.

\section{8. まとめと展望}

散乱系媒体の定量的な分光は散乱体内の光伝播のモデ ル化と計算機の発達によってようやく可能となってまだ 10 年程度であるが, この分野の発展は目覚ましく, 均質 な散乱媒体の定量化から, 不均質媒体の定量化へと進ん でいる。不均質媒体の定量化を目指す最も高度な技術が 光CTであって, 医療や脳科学への応用が期待されてい る.しかし, 生体組織による光の強い散乱のために再構 成される画像の質がX線CTやMRIに比較すると劣ることは 否めない.

また，透過性の高い近赤外光といえども $10 \mathrm{~cm}$ ら大き な組織で透過した拡散光を検出することは現在の技術で は困難である。そこで拡散透過光だけでなく，いわゆる 拡散反射光を用いて頭部の限られた領域内で断層像を得 ようとする試み14)も行われている。拡散反射光を利用し て脳機能を研究する技術として光トポグラフィが実用化 されているが, 深さ方向の情報を得ることが困難であ る. そのため, 特に, 脳機能を探るために今後, 拡散反

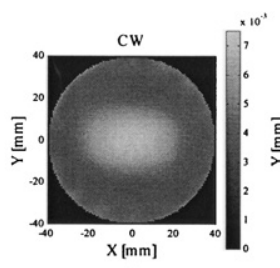

(a)

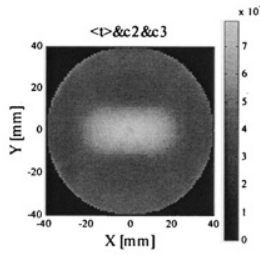

(d)

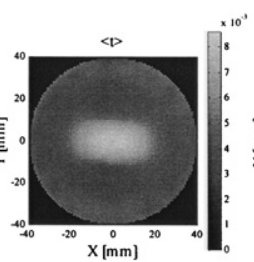

(b)

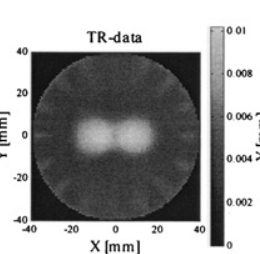

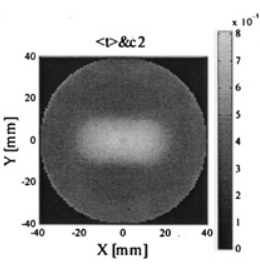

(c)
Fig. 6 Reconstructed absorption images of a simulated 2-D phantom having two small absorbers. The images were reconstructed from (a) $\mathrm{CW}$, (b) $<\mathrm{t}>$, (c) $<\mathrm{t}>$ \& c2, (d) $<$ t $>$ c $2 \&$ c3, (e) time-resolved, and (f) normalized time-resolved data.

射光を用いた反射型光CTの研究開発が盛んに行われるも のと予想される。

測定手法として連続光, 強度変調光, 極短パルス光を 用いる方法を紹介したが，それぞれに長所と短所を持っ ている．連続光を用いた高速光CTによる生理学的変化の 測定や，時間分解測定法を用いた光CTによる画像の質の 向上など，はそれぞれ今後さらに研究開発が進められ て, 乳癌診断や脳機能診断などで臨床応用されて行くも のと考えられる。

\section{参考文献}

1）田村守：「光を使った生体計測一光CTへの道一」O plus E, No. 90, 1987-5, No. 101 , 1988-4.

2）山田幸生, 高橋ゆかり：「医学・生物学における光と生体組 織の相互作用掞よび光によるイメージング」機械技術研究所 所報 49 (1995) 1.

3) A. Sassaroli, F. Martelli, Y. Tanikawa, K. Tanaka, R. Araki, Y. Onodera, and Y. Yamada: Opt. Rev. 7 (2000) 420.

4) 久保司郎: 逆問題 (培風館, 1992).

5) S. R. Arridge, M. Schweiger, and D. T. Delpy: SPIE Proc. 1767 (1992) 372

6) C. H. Schmitz, M. Loecker, J. M. Lasker, A. H. Hielscher, and R. L. Barbour: Rev. Sci. Instrum. 73 (2002) 429.

7) R. L. Barbour, H. L. Graber, Y. Pei, S. Zhong, and C. H. Schmitz: J. Opt. Soc. Am. A 18 (2001) 3018.

8) T. O. McBridge, B. W. Pogue, S. Jiang, U. L. Oesterberg, and K. D. Paulsen: Rev. Sci. Instrum. 72 (2001) 1817.

9) B. W. Pogue, S. Geimer, T. O. McBride, S. Jiang, U. L. Oesterberg, and K. D. Paulsen: Appl. Opt. 40 (2001) 588.

10) H. Eda, I. Oda, Y. Ito, Y. Wada, Y. Oikawa, Y. Tsunazawa, M. Takada, Y. Tsuchiya, Y. Yamashita, M. Oda, A. Sassaroli, Y. Yamada, and M. Tamura: Rev. Sci. Instrum. 70 (1999) 3595.

11) F. E. W. Schmidt, M. E. Fry, E. M. C. Hillman, J. C. Hebden, and D. T. Delpy: Rev. Sci. Instrum. 71 (2000) 256.

12) J. C. Hebden, H. Vee nstra, H. Dehghani, E. M. C. Hillman, M. Schweiger., S. R. Arridge, and D. T. Delpy: Appl. Opt. 40 (2001) 3278.

13) F. Gao, H. Zhao, and Y. Yamada: Appl. Opt. 41 (2002) 778.

14) A. Y. Bluestone, G. Abdoulaev, C. H. Schmitz, R. L. Barbour, and A. H. Hielscher: Opt. Exp. 9 (2001) 272. 